\title{
Climate change, water resources and sustainable development in the arid and semi-arid lands of Central Asia in the past 30 years
}

\author{
YU Yang ${ }^{1,2,3}$, PI Yuanyue ${ }^{1,4}$, YU Xiang ${ }^{1,5}$, TA Zhijie ${ }^{1,6}$, SUN Lingxiao ${ }^{1,6}$, Markus DISSE ${ }^{7}$, \\ ZENG Fanjiang $^{1,3}$, LI Yaoming ${ }^{1,2}$, CHEN Xi $^{1,2}$, YU Ruide ${ }^{1,8^{*}}$ \\ ${ }^{1}$ Xinjiang Institute of Ecology and Geography, Chinese Academy of Sciences, Urumqi 830011, China; \\ ${ }^{2}$ Research Center for Ecology and Environment of Central Asia, Chinese Academy of Sciences, Urumqi 830011, China; \\ ${ }^{3}$ Cele National Station of Observation and Research for Desert-Grassland Ecosystem, Cele 848300, China; \\ ${ }^{4}$ University of Chinese Academy of Sciences, Beijing 100049, China; \\ ${ }^{5}$ Chinese Academy of Forestry, Beijing 100091, China; \\ ${ }^{6}$ State Key Laboratory of Desert and Oasis Ecology, Chinese Academy of Sciences, Urumqi 830011, China; \\ ${ }^{7}$ Chair of Hydrology and River Basin Management, Technical University of Munich, Munich 80333, Germany; \\ ${ }^{8}$ School of Environment and Material Science, Yantai University, Yantai 264005, China
}

\begin{abstract}
The countries of Central Asia are collectively known as the five "-stans": Uzbekistan, Kyrgyzstan, Turkmenistan, Tajikistan and Kazakhstan. In recent times, the Central Asian region has been affected by the shrinkage of the Aral Sea, widespread desertification, soil salinization, biodiversity loss, frequent sand storms, and many other ecological disasters. This paper is a review article based upon the collection, identification and collation of previous studies of environmental changes and regional developments in Central Asia in the past 30 years. Most recent studies have reached a consensus that the temperature rise in Central Asia is occurring faster than the global average. This warming trend will not only result in a higher evaporation in the basin oases, but also to a significant retreat of glaciers in the mountainous areas. Water is the key to sustainable development in the arid and semi-arid regions in Central Asia. The uneven distribution, over consumption, and pollution of water resources in Central Asia have caused severe water supply problems, which have been affecting regional harmony and development for the past 30 years. The widespread and significant land use changes in the 1990s could be used to improve our understanding of natural variability and human interaction in the region. There has been a positive trend of trans-border cooperation among the Central Asian countries in recent years. International attention has grown and research projects have been initiated to provide water and ecosystem protection in Central Asia. However, the agreements that have been reached might not be able to deliver practical action in time to prevent severe ecological disasters. Water management should be based on hydrographic borders and ministries should be able to make timely decisions without political intervention. Fully integrated management of water resources, land use and industrial development is essential in Central Asia. The ecological crisis should provide sufficient motivation to reach a consensus on unified water management throughout the region.
\end{abstract}

Keywords: Central Asia; climate change; water resources; arid and semi-arid lands; land use changes; sustainable development; socio-economic development

Citation: YU Yang, PI Yuanyue, YU Xiang, TA Zhijie, SUN Lingxiao, Markus DISSE, ZENG Fanjiang, LI Yaoming, CHEN Xi, YU Ruide. 2019. Climate change, water resources and sustainable development in the arid and semi-arid lands of Central Asia in the past 30 years. Journal of Arid Land, 11(1): 1-14. https://doi.org/10.1007/s40333-018-0073-3

*Corresponding author: YU Ruide (E-mail: ruideyu@ms.xjb.ac.cn)

Received 2018-09-16; revised 2018-11-15; accepted 2018-11-26

(C) The Author(s) 2019. This article is published with open access at link.springer.com 


\section{Introduction}

The term "Central Asia", also referred to as "Middle Asia" (Soviet parlance) or "Inner Asia", is used to describe the hinterland of Asia. The region is located far from oceans in every direction. According to the United Nations Educational, Scientific and Cultural Organization (UNESCO) definition, Central Asia has a border with the Caspian Sea to the west, the Da Hinggan Mountains to the east, the Altay Mountains to the north, and the Himalaya Mountains to the south. This vague definition has made it difficult for geographers to conduct regional research. Many researchers (e.g., Aizen et al., 2007; Cowan et al., 2007; Karthe et al., 2015) consider Mongolia, western China, Russian Siberia, northern Iran, Afghanistan, Pakistan and India to be within Central Asia. In a narrow sense, however, Central Asia is comprised of the five "-stans": Uzbekistan, Kyrgyzstan, Turkmenistan, Tajikistan and Kazakhstan (Lioubimtseva et al., 2005; Rakhmatullaev and Abdullaev, 2014).

With a total area of $4 \times 10^{8} \mathrm{hm}^{2}$ and a total population of around $65 \times 10^{6}$, Central Asia mainly consists of arid and semi-arid areas. Because of the region's continental location, climate and water resources have been key factors in its social and economic development since historical times. During the past 30 years, the temperature rise in Central Asia has been reported to be higher than the global average (Zhang et al., 2010; Hu et al., 2014), which has accelerated evaporation losses (Lioubimtseva and Henebry, 2009) and caused lakes to dry up (Klein et al., 2014). The shortage of water resources has had a large influence on land use changes (Saiko and Zonn, 2000; Chalov et al., 2013). Since the collapse of the former Soviet Union in 1991, a vast area of farmland has been abandoned, which has modified the landscapes and water cycles in Central Asia (Lioubimtseva et al., 2005). Kyrgyzstan and Tajikistan are mostly located in the upper reaches of trans-border rivers, and have a shared responsibility for water management with Uzbekistan, Turkmenistan and Kazakhstan (Puri and Aureli, 2010). The study of trans-border rivers is a sensitive matter for political and historical reasons. A massive number of rivers, lakes and groundwater aquifers in the region are trans-border water bodies. Therefore, cross-border cooperation is essential in the management of Central Asian water resources.

In recent years, the Aral Sea ecological disaster has received broad international attention (Erdinger et al., 2011; Cretaux et al., 2013; Rafikov and Gulnora, 2014; Micklin, 2016). Desertification, soil salinization, biodiversity loss, frequent sand storms, and many other natural disasters in Central Asia have been studied by researchers from across the world (Riedel et al., 2011; Indoitu et al., 2012; Jin et al., 2012; White, 2013; Stunzhas, 2016). Climate change, population growth, over-exploitation of water resources and inappropriate land management are considered to be responsible for environmental deterioration in Central Asia (Deng et al., 2010; Agadjanian et al., 2013; Demin, 2016; Kuzmina and Treshkin, 2016). Divergent economic interests and the conflicting needs, goals and priorities of the five Central Asian countries remain as an impediment to achieving the cooperation necessary for ecological rehabilitation and sustainable management in the region (Howard and Howard, 2016).

This paper is a review of the environmental changes and regional developments in Central Asia over the past 30 years. It is extremely important to understand the research progress and actual changes that have occurred in Central Asian countries since the collapse of the Soviet Union, because this may provide guidance for the future sustainable development of the whole region. Determining the spatiotemporal patterns of climate, water resources, land use, and socio-economic changes may enable regional developments to be better balanced in the future. Moreover, there is a general lack of research data in geoscience studies in Central Asia. A summary of the available resources and trans-border research cooperation are necessary for the execution of further related studies.

\section{Methods}

A literature review that considered climate change, water resources, and the social and economic development of Central Asia was conducted from January 1988 to December 2017 (Fig. 1). The 
ScienceDirect (Elsevier) database was consulted. The keywords used in searches were "climate+Central Asia", "water+Central Asia", "land+Central Asia", and "social/economic development+Central Asia". If the search words appeared in the title, abstract, or keywords of an article, then the article was preliminarily selected. A validation process was then conducted to check for double counting and erroneous articles. Finally, the total number of articles in each category was recorded. Any studies that used remote sensing were placed into a separate category.

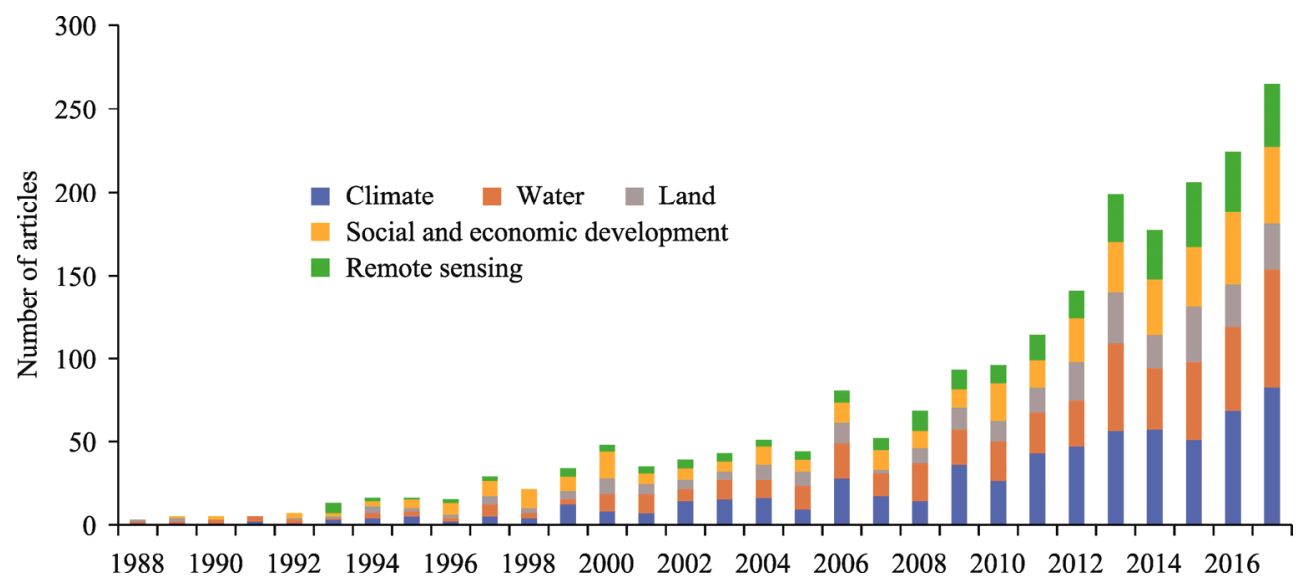

Fig. 1 Increase in the number of English language articles in geoscience studies of Central Asia from 1988 to 2017

There were 1846 English language articles in total: 635 regarding climate, 510 regarding water, 295 regarding land, and 406 regarding social and economic development. Among them, 298 used remote sensing technology as the major research methodology. Most articles were written by Chinese, German and American authors, but this does not mean that these countries have taken the lead in geoscience research in Central Asia. Before the 1990s, Soviet scientists conducted more comprehensive studies (mostly published in Russian) of the meteorology, hydrology, geography and geology of "Middle Asia". In the past 30 years, there have been large advances in basic scientific research in this region. Scientists have still found it difficult to acquire data, which is partly the reason why remote sensing is a popular technique in studies of Central Asia (De Beurs and Henebry, 2004; Propastin et al., 2008; Zhang et al., 2010; Conrad et al., 2011; Zhou et al., 2013; Klein et al., 2014; Beurs et al., 2015).

\section{Environmental changes in Central Asia}

\subsection{Climate change}

In the past 100 years, the global climate system has undergone a significant change characterized by greenhouse gas emissions and global warming. According to the IPCC fifth assessment report, the global warming trend is still continuing, and the average temperature of the global surface has increased by $0.85^{\circ} \mathrm{C}$ (Stocker et al., 2013). Central Asia is one of the largest arid and semi-arid areas in the world (Knorr et al., 2001; Xu et al., 2007; Gessner et al., 2013). The natural ecosystems of Central Asia are very sensitive and vulnerable to climate change (Chen, 2012; Yin et al., 2016). Hu et al. (2014) analyzed the near-surface air temperature changes in Central Asia from 1979 to 2011 using observations from 81 meteorological stations. They found that the rise in air temperature in Central Asia occurred at a faster rate than that in surrounding areas or than the global average. The warming trend is noticeable, especially in the northern part of the region and during the cold season. The surface air temperature over Central Asia will rise between $3^{\circ} \mathrm{C}-7^{\circ} \mathrm{C}$ on average in the future. The largest increase in near-surface air temperature occurred in spring. According to the projected emission scenarios for the period of 2071-2100, the warming trend in summer is expected to increase (Ozturk et al., 2017). Many climate models (Pollner et al., 2008; 
Lioubimtseva and Henebry, 2009; Hu et al., 2014) have been used to project the temperature rise in the $21^{\text {st }}$ century (Table 1 ). Most recent studies have reached a consensus that the temperature rise in Central Asia has occurred faster than the global average over the past 30 years. This warming trend will not only result in a higher evaporation in the basin oases, but also a significant retreat of glaciers in the mountainous areas (Sorg et al., 2012, Unger-Shayesteh et al., 2013).

Table 1 Temperature rise in Central Asia based on different studies

\begin{tabular}{cccc}
\hline $\begin{array}{c}\text { Temperature rise } \\
\left({ }^{\circ} \mathrm{C} / 10 \mathrm{a}\right)\end{array}$ & Period & Database and methods & References \\
\hline 0.38 & $1980-1999$, & World Bank, GCMs & Pollner et al. (2008) \\
0.16 & $2030-2049$ & Observations from 61 stations & Wang et al. (2008) \\
$0.28-0.48$ & $1901-2003$ & CRU, AOGCMs & Lioubimtseva and \\
$0.40-0.50$ & $1961-2080$ & Henebry (2009) \\
0.07 & $1971-2000-2011$ & CRU & Huang et al. (2013) \\
$0.36-0.42$ & $1979-2011$ & Observations from 81 stations, CRU, CFSR, & Huen et al. (2013) \\
$0.36-0.47$ & $1980-2011$ & ERA-Interim, MERRA (2014) \\
0.27 & $1960-2012$ & Observations from 31 stations & Xu et al. (2015) \\
\hline
\end{tabular}

Note: GCMs, General Circulation Models; CRU, Climate Research Unit; AOGCMs, Atmosphere Ocean Global Climate Models; GISS, Goddard Institute for Space Studies; CFSR, Climate Forecast System Reanalysis; ERA-Interim, European Centre for Medium-Range Weather Forecasts Interim Reanalysis; MERRA, Modern Era Retrospective-Analysis; NOAA, National Oceanic and Atmospheric Administration.

Spatial patterns of precipitation in Central Asia are strongly related to elevation (Klein et al., 2012; Chen et al., 2013). Annual precipitation in the mountainous areas is often more than 1000 $\mathrm{mm}$, and even reaches $2000 \mathrm{~mm}$ in some southern parts of Central Asia. In the basin areas of Uzbekistan, Turkmenistan and Tajikistan and the southern parts of Kazakhstan, annual precipitation is less than $100 \mathrm{~mm}$, but the summer temperature reaches more than $24^{\circ} \mathrm{C}$ on average. This has caused severe land desertification and water shortage problems.

Is there a significant response to the temperature rise in Central Asia under the background of global warming? Many researchers have studied the characteristics of climate change in Central Asia and their relationship with global warming from different perspectives. Some previous studies have shown that the convergence and divergence of atmospheric moisture will significantly increase the moisture content in the atmosphere, resulting in a pattern of "dry gets drier, wet gets wetter" (Allen and Ingram, 2002; Dore, 2005; Held and Soden, 2006). However, several recent studies have indicated the occurrence of the opposite pattern, namely "dry becomes wet, wet becomes dry" (Greve et al., 2014). The average precipitation in the arid regions has increased in both measured data and climate models over the past 30 years (Donat et al., 2016). In Central Asia, the annual precipitation has generally increased during the past 80 years, especially in winter (Chen et al., 2011). There was a significant increasing trend in precipitation in the southeast of Central Asia during 1960-2013 (Song and Bai, 2016).

Climate change in Central Asia is related to many factors, such as sea surface temperature, large-scale meridional circulation, and the El Niño-Southern Oscillation (ENSO). Some researchers have studied the mechanism of climate change in the arid and semi-arid regions of Central Asia. Lioubimtseva and Cole (2006) reported that the intensified westerly circulation and its southward movement may be the main reason for the increased precipitation over Central Asia in the context of global warming. Hu et al. (2017) used the Global Precipitation Climatology Centre (GPCC) V7 dataset to explore the spatiotemporal variations of annual precipitation. Their results indicate that annual precipitation over Central Asia is closely related to the ENSO. The ocean surface temperature anomaly has a significant effect on temperature over Central Asia. The winter temperature is much warmer when a positive sea surface temperature anomaly occurs in the equatorial central-eastern Pacific (ECEP) from autumn to winter, and vice versa. The summer temperature is much warmer (cooler) when there is a higher (lower) ocean surface temperature in the ECEP (Wang et al., 2011). Summer precipitation and temperature anomalies in Central Asia 
are closely related to a large-scale meridional circulation. Winter precipitation and temperature anomalies are closely connected to the singularity of the zonal circulation in the tropics. The Ural Mountains trough (ridge), western Pacific subtropical high and Arabia trough (ridge) are the main weather systems affecting the climate of Central Asia (Wang and Wei, 2012). The annual temperature and precipitation have shown a significant increasing trend, which are more rapid in the plains than in the mountainous areas of the Syr Darya Basin over Central Asia (Yao and Chen, 2015).

\subsection{Water resources}

There are more than $1 \times 10^{4}$ rivers and $1 \times 10^{4}$ natural lakes in Central Asia. The lake area is more than $5 \times 10^{5} \mathrm{~km}^{2}$, about $1 / 5$ of the Earth's total lake area. However, most regions face water scarcity problems for two major reasons. First, there is a remarkably uneven distribution of water resources in the region, creating competition between up and downstream water users (Chalov et al., 2013). Most rivers originate from the mountainous regions of Tajikistan and Kyrgyzstan, providing relatively abundant fresh water for farmlands, forests, livestock, industry and domestic use. In contrast, Uzbekistan, Turkmenistan and Kazakhstan are facing severe water scarcity problems. Second, water quality problems are enhancing the shortage of fresh water. Salts, agrochemicals, organic pollutants and heavy metals are frequent water quality impairments in the downstream parts of most river catchments (Groll et al., 2015). Furthermore, many lake basins (including the Aral Sea, Caspian Sea, Balkhash Lake and Issyk-kul Basin) have experienced a reduction of water supply, lake area shrinkage and ecosystem degradation caused by water shortages and ecological deterioration (Table 2).

Table 2 The main rivers and lakes in Central Asia

\begin{tabular}{|c|c|c|c|c|c|}
\hline \multicolumn{2}{|c|}{ Rivers/Lakes } & \multirow{2}{*}{$\begin{array}{c}\text { Riparian countries } \\
\text { China, Kazakhstan, Russia }\end{array}$} & \multirow{2}{*}{$\begin{array}{c}\begin{array}{c}\text { Length } \\
(\mathrm{km})\end{array} \\
4248\end{array}$} & \multirow{2}{*}{$\begin{array}{c}\begin{array}{c}\text { Catchment } \\
\text { area } \\
\left(10^{3} \mathrm{~km}^{2}\right)\end{array} \\
1640\end{array}$} & \multirow{2}{*}{$\begin{array}{c}\begin{array}{c}\text { Runoff } \\
\left(10^{9} \mathrm{~m}^{3}\right)\end{array} \\
95.0 \text { (Discharge in China) }\end{array}$} \\
\hline Rivers & Ertix & & & & \\
\hline & Syr Darya & $\begin{array}{c}\text { Kyrgyzstan, Uzbekistan, Tajikistan, } \\
\text { Kazakhstan }\end{array}$ & 3018 & 783 & $\begin{array}{l}34.1 \text { (Discharge in } \\
\text { Kyrgyzstan) }\end{array}$ \\
\hline & Amu Darya & $\begin{array}{c}\text { Tajikistan, Afghanistan, Uzbekistan, } \\
\text { Turkmenistan }\end{array}$ & 2540 & 465 & $\begin{array}{l}56.4 \text { (Runoff in } \\
\text { Uzbekistan) }\end{array}$ \\
\hline & Ural & Russia, Kazakhstan & 2534 & 231 & 8.0 (Discharge in Russia) \\
\hline & Ili & Kazakhstan, China & 1236 & 151 & 12.6 (Runoff in China) \\
\hline \multirow{8}{*}{ Lakes } & Chu & Kyrgyzstan, Kazakhstan & 1186 & 63 & $\begin{array}{l}6.6 \text { (Runoff in } \\
\text { Kazakhstan) }\end{array}$ \\
\hline & Zeravshan & Tajikistan, Uzbekistan & 877 & 18 & $\begin{array}{l}5.1 \text { (Discharge in } \\
\text { Tajikistan) }\end{array}$ \\
\hline & Talas & Kyrgyzstan, Kazakhstan & 661 & 53 & $\begin{array}{l}1.8 \text { (Runoff in } \\
\text { Kazakhstan) }\end{array}$ \\
\hline & $\begin{array}{l}\text { Caspian } \\
\text { Sea }\end{array}$ & Russia, Kazakhstan, Turkmenistan, Iran & - & 3034 & - \\
\hline & Aral Sea & Kazakhstan, Uzbekistan & - & 796 & - \\
\hline & Balkhash & Kazakhstan, China & - & 413 & - \\
\hline & Ala Kul & Kazakhstan & - & 69 & - \\
\hline & Issyk Kul & Kyrgyzstan & - & 22 & - \\
\hline
\end{tabular}

Note: Data sources: Yang and Du (2013); Li et al. (2017); and the Research Center for Ecology and Environment of Central Asia, Chinese Academy of Sciences. -, data not applicable.

Due to low precipitation in the basin area, nearly $98 \%$ of the river discharge originates from the mountainous regions. The Tianshan Mountains and Pamir Mountains are considered to be the fresh water tower of Central Asia. Based on statistical data for the past 30 years, glacier and snow meltwater contributes $20 \%-60 \%$ of the total runoff from the Tianshan Mountains, which is crucial for ensuring seasonal water availability. With higher rainfall amount in the mountains, forests also play an important role in fresh water storage and generation in the arid and semi-arid regions, but the ratios of rainfall to runoff are still lower than those in humid regions. Kyrgyzstan and Tajikistan are mostly located in the upper reaches of trans-border rivers, with an abundant water 
supply from the mountains. In the lower reaches, water users from Uzbekistan, Turkmenistan and Kazakhstan often complain about insufficient river outflow into their countries (Fig. 2). There are two major characteristics of dryland rivers in Central Asia. First, the seasonal fluctuations of the hydrographs are often large (Yu et al., 2015). Peak flows normally occur in summer, and most rivers have a glacier period in winter. Intermittent streams and unstable flow channels are quite common. Second, water volumes are often much lower in the downstream, with less precipitation, higher evaporation, and infiltration losses, as well as greater water consumption. Temporary flow in dryland rivers has a special biological significance, enabling certain species to breed while eliminating others (Karthe, 2018). In the arid and semi-arid regions of Central Asia, the growth of most natural vegetation (also called Tugai vegetation) is highly reliant on groundwater conditions. Compared with surface water abstraction, groundwater exploitation and utilization rates are relatively low, and groundwater is mainly for irrigation and domestic use (Liu et al., 2018). Tugai vegetation has a strong tolerance to dry and saline soil (Thevs et al., 2012). In farmlands, crops often have to be grown under water-stressed conditions.

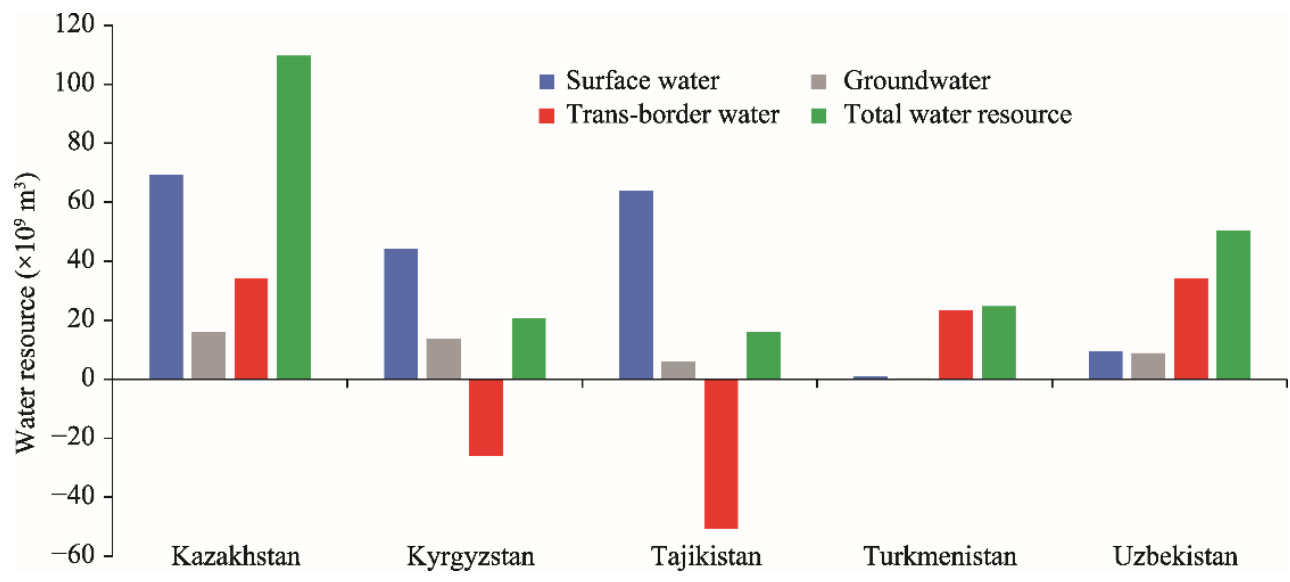

Fig. 2 Water resources of Central Asia. The double-counting of the interface between surface water and groundwater was eliminated when calculating the total water resource. The negative value of trans-border water represents the net outflow out of the country. Data source: Deng et al. (2010).

An example of an ecological catastrophe in Central Asia is the shrinkage of the Aral Sea. Because of water withdrawal for irrigation and domestic use from both tributaries, i.e., the Amu Darya and Syr Darya (Erdinger et al., 2011), the size of the Aral Sea has declined dramatically from $4 \times 10^{5} \mathrm{~km}^{2}$ in the early 1990 s to approximately $1 \times 10^{5} \mathrm{~km}^{2}$ in 2012 (Klein et al., 2014). Many leaders from Central Asian countries and the United Nations have addressed the crisis. However, the provision of a sustainable water management plan in the Aral Sea Basin (including the Amu Darya and Syr Darya oases) is currently proceeding too slowly to prevent further water losses and environmental deterioration. The Aral Sea may vanish, as happened to Lop Nor in Xinjiang of China.

Where there is sufficient data, hydrological models can be successfully applied at the large basin scale in the arid and semi-arid lands (Yu et al., 2017). However, in studies of Central Asia, there are often problems caused by the trans-border nature of water resources. According to the CAWater-Info (2018), approximately $30 \%$ of regional groundwater is stored within a trans-boundary aquifer in the Aral Sea Basin, and the figure is much higher in the mountainous regions (e.g., Tianshan Mountains). All of the large rivers in Central Asia are basically trans-border rivers, implying that the related regions share natural resources and responsibilities, which require interstate regulation and mutual protection measures. Unfortunately, political rivalries, economic competition and nationalism have seriously undermined efforts to solve trans-border water problems during the past 30 years (Howard and Howard, 2016). 


\section{Regional developments in Central Asia}

\subsection{Land use changes}

From southeast to northwest, the elevation of Central Asia drops from 7495 to $132 \mathrm{~m}$. The vast region between the Pamir Mountains and the Caspian Sea is mainly comprised of desert, semidesert and steppe. The main regions include Kazakhskiy and Melkosopochnik in the north, the Turan Plain in the middle, the Caspian Plain in the west, and the Karakum Desert in the south. In the arid and semi-arid regions of Kazakhstan, Uzbekistan and Turkmenistan, there are large irrigated areas with bare lands and sparse vegetation (Klein et al., 2012). The mountain landscapes of Kyrgyzstan and Tajikistan in the southeast of Central Asia contain glaciers, snow, coniferous forests and grasslands. Modern vegetation in the arid and semi-arid regions of Central Asia evolved from ancient Mediterranean species, which has a subtropical genetic background.

The prosperity of Central Asia, as an agrarian region since ancient times, has always been very closely linked to land use. Today, farming still employs about $60 \%$ of the rural population. In the Aral Sea Basin, of the $1.55 \times 10^{8} \mathrm{hm}^{2}$ total land area, $0.59 \times 10^{8} \mathrm{hm}^{2}$ is considered cultivable, of which only about $0.10 \times 10^{8} \mathrm{hm}^{2}$ is actually used. About half of the cultivated land is located in oases, with fertile soils (CAWater-Info, 2018). Since the disintegration of the Soviet Union, the most significant land use changes in Central Asia have been farmland abandonment and reclamation. Based on remote sensing technology, Chen et al. (2013) found that the agricultural area in Central Asia fell from $1.03 \times 10^{8} \mathrm{hm}^{2}$ in 1990 to $0.54 \times 10^{8} \mathrm{hm}^{2}$ in 2000 , and then increased to $0.70 \times 10^{8} \mathrm{hm}^{2}$ in 2009 (Fig. 3). The area of steppe, forest and desert increased from 1990 to 2000 , and then decreased slightly with the reclamation of farmlands. The Aral Sea shrank by $63.80 \%$ from 1990 to 2009, whereas there was no significant change in the area of Balkhash and Issyk Kul. Additionally, crop productivity dropped dramatically from 1992 to 1995, then steadily increased to its former level, and remained stable in the $21^{\text {st }}$ century (Chen et al., 2013).

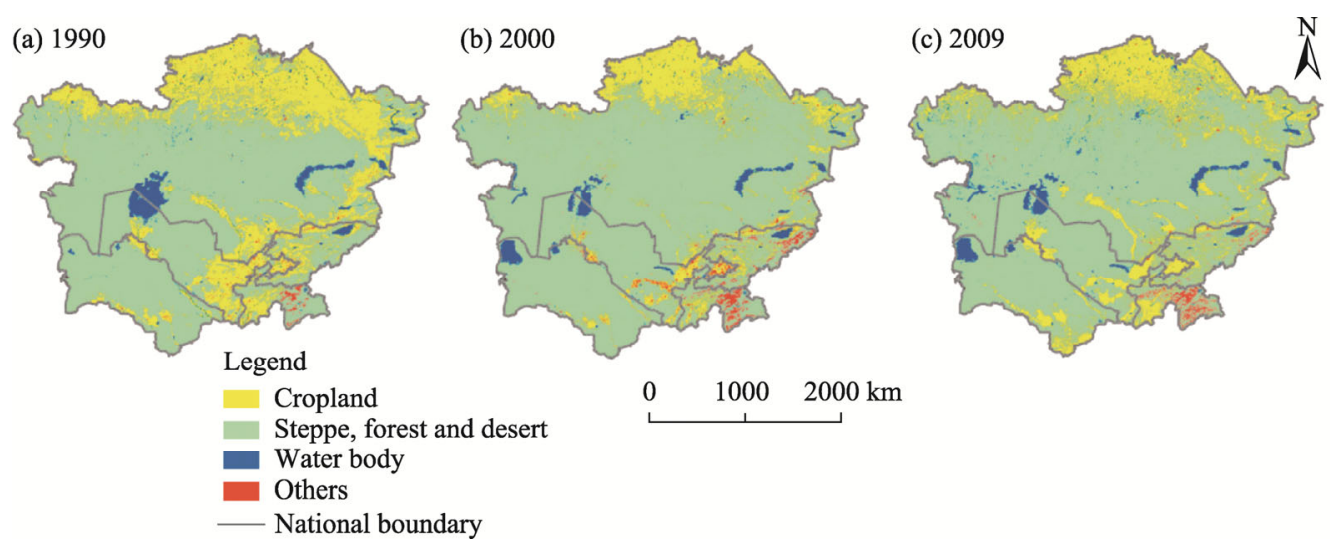

Fig. 3 Land use changes in Central Asia from 1990 to 2009. Data source: Chen et al. (2013).

With the collapse of the Soviet Union in 1991, Central Asian countries experienced a transition from a centrally planned economy to a competitive social market economy, resulting in a profound restructuring of Central Asia's agricultural sector (Baumann et al., 2011). Markets were liberalized and foreign competition emerged (Ioffe et al., 2004). Massive landowners emerged and work forces migrated from the countryside to the cities (Lerman and Shagaida, 2007). A substantial number of farmlands were abandoned during the period that has been referred to as 'the most widespread and abrupt episode of land change in the $20^{\text {th }}$ century' (Kuemmerle et al., 2011). The farmlands were later reclaimed and the landscape was renewed. While the land use changes were regulated by humans, natural conditions (e.g., temperature rise, glacier melting, water availability, precipitation and evaporation) also played a role in land use changes.

Soil salinization is another problem in the arid and semi-arid lands of Central Asia. With high water losses, low precipitation and insufficient irrigation water, land salinization has affected over 
47.5\% of the irrigated land in Central Asia (33.0\% in Kazakhstan, $11.5 \%$ in Kyrgyzstan, $16.0 \%$ in Tajikistan, $95.9 \%$ in Turkmenistan and $50.1 \%$ in Uzbekistan) (Hamidov et al., 2016). Salinization is a serious threat to crop production in the arid and semi-arid regions (Kushiev et al., 2005). Sodic and saline soils are distributed throughout these regions. The formation and evolution of the soil patterns are linked to particular combinations of climatic and hydrological conditions in most parts of Central Asia.

\subsection{Population and economic growth}

The total population of Central Asia was $52.3 \times 10^{6}$ in 1993 , which increased to $71.9 \times 10^{6}$ in 2017 , with an annual growth rate of $0.81 \%$. The population has been gradually and slowly increasing during the past three decades (Fig. 4). From 1993 to 2017, the following population increases were recorded: Kazakhstan from $16.4 \times 10^{6}$ to $18.4 \times 10^{6}$, Kyrgyzstan from $4.52 \times 10^{6}$ to $6.13 \times 10^{6}$, Tajikistan from $5.57 \times 10^{6}$ to $9.11 \times 10^{6}$, Turkmenistan from $3.99 \times 10^{6}$ to $5.85 \times 10^{6}$, and Uzbekistan from $21.9 \times 10^{6}$ to $32.4 \times 10^{6}$. Considering the vast territory and low population density, the population growth in Central Asia should not generate much pressure on water resources and land use at the national level.

(a) Population $\left(\times 10^{6}\right)$

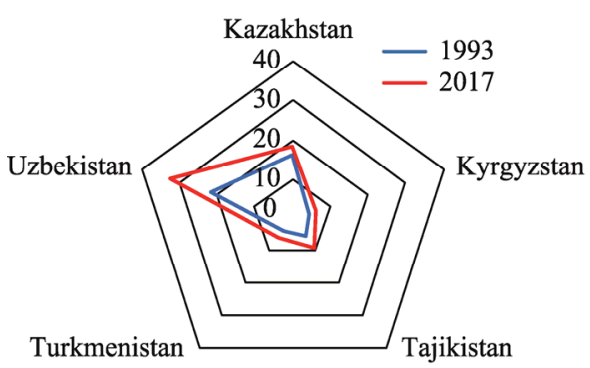

(b) GDP per capita (US dollar)

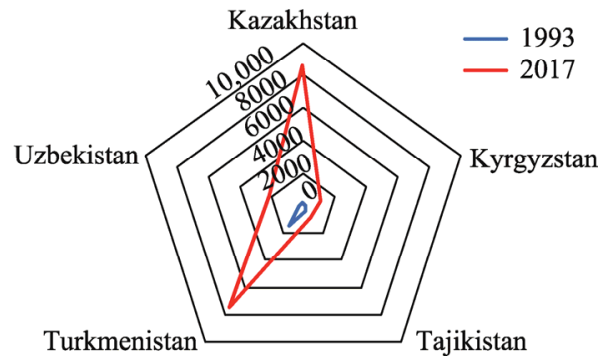

Fig. 4 Population and GDP per capita in Central Asia in 1993 and 2017. Data source: the Research Center for Ecology and Environment of Central Asia, Chinese Academy of Sciences.

During the past 30 years, Central Asia has experienced an economic boom. After a short period of economic recession from 1991 to 1995 , the resurgence of the economy has been rapid and steady. The GDP per capita of Kazakhstan increased more than 30-fold from 1993 to 2017. The other countries in the region have also experienced rapid economic and productivity growth. However, industrial development has been uneven throughout the region and has potential weaknesses. Central Asian countries, especially Kazakhstan, Turkmenistan and Uzbekistan, possess a world-famous sedimentary basin that contains huge petroleum reserves ( $\mathrm{Gu}$ and $\mathrm{Yu}$, 2017). Therefore, foreign investment has been attracted to assist these countries to develop the secondary industries. In contrast, Kyrgyzstan and Tajikistan have developed hydropower due to their hypsographic advantages and abundance of water resources. These natural-resource-oriented developments have caused many practical problems. The competition between upstream hydropower and downstream irrigation has become a significant issue in recent years. Modern management measures have generally not been applied in agricultural production. Science and technology are slowly transforming traditional farming methods. The electricity industry, mining, mechanical engineering, and a number of other industries are struggling in most of the region. The overall economic situation is not balanced and powerful enough to resist an international financial crisis.

\section{Discussion}

Central Asia is one of the world's largest closed drainage basins with more than $1 \times 10^{4}$ rivers and $1 \times 10^{4}$ natural lakes. The vast areas of arid and semi-arid lands are highly dependent on rivers and lakes as sources of freshwater. Significant changes in water bodies have occurred in the past three decades, including large inland rivers and the Aral Sea. The shrinkage of the Aral Sea cannot be 
solely attributed to water abstraction over the past 30 years. Varis (2014) has proposed that irrigation-intensive industries in the former Soviet Union have drained water bodies in the Central Asian region. It is true that massive amounts of water consumption have resulted in a reduction in the water area of the Aral Sea since the 1960s (Saiko and Zonn, 2000), but the situation has not substantially changed in the last three decades. Water inflows are much lower than water losses following the breakup of the Soviet Union, and the Aral Sea has gradually dried up due to excessive irrigation water use in the upper tributaries. Today, the gradual drainage of the Aral Sea is not only a regional problem, but has also become a world famous trans-national ecological disaster (Cai et al., 2003; Kitamura et al., 2006; Qadir et al., 2009; Micklin, 2016). There is an urgent need to initiate integrated water resource management in the region to ensure ecosystem protection and socio-economic sustainability in Central Asia (Kubo et al., 2009).

Climate change and water resources have a high degree of ecological and economic importance in Central Asia, where the widespread and significant land use changes since the 1990s may also help improve our understanding of natural variability and human interaction (Chen et al., 2013). Regional precipitation mainly occurs in the Pamir Mountains and Tianshan Mountains on the southeastern edge of the region. Increasing evaporation and decreasing precipitation in the vast inland regions have resulted in a reduction of river runoff from the mountains to the plain areas. Frequent extreme natural events (such as prolonged drought and flooding) could have a significant impact on ecosystem structure and function in Central Asia (Wu et al., 2011; Zerbe and Thevs, 2011). Despite a few watershed or basin scale studies, the ecosystem responses to water availability and land use changes in Central Asia are still unclear. Temperature changes and the alternation of precipitation may also have both positive and negative impacts on ecosystems. The potential impacts of climate change and the long-term sustainability of water resources need to be further investigated (Yang et al., 2013).

Ecological and environmental problems are the main concerns of the governments of Central Asian countries. The ecosystem is fragile in the arid and semi-arid regions. Climate change and human disturbance could easily cause significant ecosystem changes or even ecological disasters (Levintanus, 1992; Erdinger et al., 2011). Spatiotemporal variations in human-induced water availability and land use changes have resulted in regional differences in ecosystem services, namely supporting services, provisioning services, regulating services and cultural services. Local residents benefit from and rely on those ecosystem services, which have been affected by changes in a number of factors, including demographic, socio-economic, political, physical and biological conditions. Dryland ecosystems should be managed in a way that enables them to provide ecosystem services that meet human demands for social development. As well as the arid and semi-arid lands of Central Asia, the mountainous regions are also vulnerable to ecological disasters (Halvorson and Hamilton, 2007). It is therefore necessary to better understand the influences and functions of ecosystem services to support policy-making and integrated management measures in Central Asia. To understand the complexity of local socio-economic and water policies that are related to sustainable development, more comprehensive and systematic studies need to be conducted at varying scales.

Extensive land use changes and migrations have occurred from the transition of the Soviet planned economy to the current market economy. Poorly managed farmlands have led to food shortages, land degradation, biodiversity loss and desertification (Gintzburger et al., 2003). Regional networks for supplementary irrigation and improved water management, crop production and rangeland management are badly needed for the five Central Asian countries. A reduction in water supply will cause economic losses and have economy-wide repercussions on employment rates, as well as the degradation of irrigated lands in downstream countries (Bekchanov and Lamers, 2016). Researchers have demanded a change in policies towards the support of integrated crop production and livestock management (Suleimenov, 2014). Studies of natural resources and environmental problems are important for ecosystem protection and socio-economic development. Agricultural production and natural resource exploitation should be managed in a sustainable way that will benefit future generations. Given that water is the key factor affecting agriculture in Central Asia, water use efficiency and agricultural productivity 
should be emphasized in the future (Hojyaz et al., 2013; Devkota et al., 2015).

In general, there has been a tendency to reach water management agreements based on trans-border cooperation among the Central Asian countries in recent years (Ambrosio, 2008; Rakhimov, 2010). As international attention on the region has grown, and the number of research projects investigating water and ecosystem protection in Central Asia have also grown (Khamzayeva et al., 2009; Libert and Lipponen, 2012). However, this might not be transformed into practical actions in time to prevent ecological disasters, such as the continued shrinkage of the Aral Sea. There is intense competition for water resources among agriculture, hydropower, domestic uses, grazing, and industrial uses along the river oases. Water allocation conflicts are most likely to occur in international catchments shared by poorer, less democratic, and politically unstable countries, which are governed by weak international water management institutions (Bernauer and Siegfried, 2012). There is a lack of cooperation among national authorities and ministries responsible for water policies and environmental protection. Such water ministries should be based on hydrographic borders and be able to make timely decisions without political intervention. It is very difficult to reach a consensus on trans-border environmental and financial legal regulations. To provide stable and sustainable ecosystem services, the fully integrated management of water, land use and industrial development is essential in Central Asia within the framework of policy, finance, environmental regulations, relevant organizations and technologies.

\section{Conclusions}

This study conducted a review of climate change, water resources and regional developments in Central Asia over the past 30 years. The different research outcomes of international researchers were considered alongside reports from the Research Center for Ecology and Environment of Central Asia, Chinese Academy of Sciences. The following important conclusions were reached.

(1) Most recent studies have shown that the temperature rise in Central Asia has been higher than that of the global average over the past 30 years. The temperature change and alternation of precipitation may have both positive and negative impacts on the fragile ecosystem of arid and semi-arid regions.

(2) The Tianshan Mountains and Pamir Mountains are considered to be the fresh water towers of Central Asia. Most of the region is facing water scarcity problems for two major reasons: the uneven distribution of water resources and the water quality problems.

(3) Trans-border water bodies are poorly managed because of the different interests of the five Central Asian countries. The over-exploitation of water resources in trans-border rivers has caused the shrinkage of the Aral Sea, along with many other ecological disasters.

(4) Since the collapse of the Soviet Union in 1991, the most significant land use changes in Central Asia have been farmland abandonment and reclamation. The agricultural area reduced by nearly $50 \%$ from 1990 to 2000 , but was steadily increased in the $21^{\text {st }}$ century. The area of steppe, forest and desert increased from 1990 to 2000, and then decreased slightly with the reclamation of farmlands.

(5) The population of the region has gradually increased over the past 30 years. Economic growth and industrial expansion have achieved varying degrees of success for all five Central Asian countries. However, the expansion has been mainly natural-resource-oriented and uneven. Environmental deterioration is becoming increasingly prominent with economic development in the Central Asian region.

\section{Acknowledgements}

This study was supported by the Strategic Priority Research Program of Chinese Academy of Sciences, Pan-Third Pole Environment Study for a Green Silk Road (XDA20060303), the Xinjiang Key Research and Development Program (2016B02017-4) and the National Nature Science Foundation of China-United Nations Environment Programme (NSFC-UNEP, 41361140361). Data collection and analysis were supported by the Research Center for Ecology and Environment of Central Asia, Chinese Academy of Sciences. Special thanks are given to the 
"High-level Talents Project" (Y871171) of Xinjiang Institute of Ecology and Geography, Chinese Academy of Sciences.

Open Access This article is distributed under the terms of the Creative Commons Attribution License which permits any use, distribution, and reproduction in any medium, provided the original author(s) and the source are credited.

The images or other third party material in this article are included in the article's Creative Commons licence, unless indicated otherwise in a credit line to the material. If material is not included in the article's Creative Commons licence and your intended use is not permitted by statutory regulation or exceeds the permitted use, you will need to obtain permission directly from the copyright holder.

To view a copy of this licence, visit http://creativecommons.org/licenses/by/4.0/.

\section{References}

Agadjanian V, Dommaraju P, Nedoluzhko L. 2013. Economic fortunes, ethnic divides, and marriage and fertility in Central Asia: Kazakhstan and Kyrgyzstan compared. Journal of Population Research, 30(3): 197-211.

Aizen V B, Aizen E M, Kuzmichenok V A. 2007. Geo-informational simulation of possible changes in Central Asian water resources. Global and Planetary Change, 56(3-4): 341-358.

Allen M, Ingram W J. 2002. Constraints on future changes in climate and the hydrologic cycle. Nature, 419: $224-232$.

Ambrosio T. 2008. Catching the 'Shanghai spirit': how the Shanghai Cooperation Organization promotes authoritarian norms in Central Asia. Europe-Asia Studies, 60(8): 1321-1344.

Baumann M, Kuemmerle T, Elbakidze M, et al. 2011. Patterns and drivers of post-socialist farmland abandonment in Western Ukraine. Land Use Policy, 28(3): 552-562.

Bekchanov M, Lamers J P A. 2016. Economic costs of reduced irrigation water availability in Uzbekistan (Central Asia). Regional Environmental Change, 16(8): 2369-2387.

Bernauer T, Siegfried T. 2012. Climate change and international water conflict in Central Asia. Journal of Peace Research, 49(1): 227-239.

Cai X, Mckinney D C, Rosegrant M W. 2003. Sustainability analysis for irrigation water management in the Aral Sea region. Agricultural Systems, 76(3): 1043-1066.

CAWater-Info. 2018. Water resources of the Aral Sea Basin. Groundwater: reserves and uses. [2018-10-06]. www.cawater-info.net/aral/groundwater_e.htm.

Chalov S, Kasimov N, Lychagin M, et al. 2013. Water resources assessment of the Selenga-Baikal river system. Geoöko, 34(1-2): 77-102.

Chen F, Huang W, Jin L, et al. 2011. Spatiotemporal precipitation variations in the arid Central Asia in the context of global warming. Science China Earth Sciences, 54(12): 1812-1821.

Chen X. 2012. Retrieval and Analysis of Evapotranspiration in Central Areas of Asia. Beijing: China Meteorological Press, 111-112. (in Chinese)

Chen X, Bai J, Li X, et al. 2013. Changes in land use/land cover and ecosystem services in Central Asia during 1990-2009. Current Opinion in Environmental Sustainability, 5(1): 116-127.

Conrad C, Colditz R R, Dech S, et al. 2011. Temporal segmentation of MODIS time series for improving crop classification in Central Asian irrigation systems. International Journal of Remote Sensing, 32(23): 8763-8778.

Cowan P J. 2007. Geographic usage of the terms Middle Asia and Central Asia. Journal of Arid Environments, 69(2): 359-363.

Cretaux J F, Letolle R, Bergé-Nguyen M. 2013. History of Aral Sea level variability and current scientific debates. Global and Planetary Change, 110: 99-113.

De Beurs K M, Henebry G M. 2004. Land surface phenology, climatic variation, and institutional change: analyzing agricultural land cover change in Kazakhstan. Remote Sensing of Environment, 89(4): 497-509.

De Beurs K M, Henebry G M, Owsley B C, et al. 2015. Using multiple remote sensing perspectives to identify and attribute land surface dynamics in Central Asia 2001-2013. Remote Sensing of Environment, 170: 48-61.

Demin A P. 2016. Problems with water use in countries of East, South and Central Asia. Geography and Natural Resources, 37(3): 181-191.

Deng M J, Long A H, Zhang Y, et al. 2010. Assessment of water resources development and utilization in the five Central Asia countries. Advances in Earth Science, 25(12): 1347-1356. (in Chinese)

Devkota M, Devkota K P, Gupta R K, et al. 2015. Conservation agriculture farming practices for optimizing water and fertilizer use efficiency in Central Asia. In: Drechsel P, Heffer P, Magen H, et al. Managing Water and Fertilizer for Sustainable 
Agricultural Intensification. Pairs: International Fertilizer Industry Association (IFA), International Water Management Institute (IWMI), International Plant Nutrition Institute (IPNI), and International Potash Institute (IPI), 242-257.

Donat M G, Lowry A L, Alexander L V, et al. 2016. More extreme precipitation in the world's dry and wet regions. Nature Climate Change, 6(5): 508-513.

Dore M H I. 2005. Climate change and changes in global precipitation patterns: What do we know? Environment International, 31(8): 1167-1181.

Erdinger L, Hollert H, Eckl P. 2011. Aral Sea: an ecological disaster zone with impact on human health. Encyclopedia of Environmental Health, 53(3): 136-144.

Gessner U, Naeimi V, Klein I, et al. 2013. The relationship between precipitation anomalies and satellite-derived vegetation activity in Central Asia. Global and Planetary Change, 110: 74-87.

Gintzburger G, Toderich K N, Mardonov B K, et al. 2003. Rangeland of the Arid and Semi-arid Zones in Uzbekistan. Montpellier: CIRAD-ICARDA, 1-426.

Greve P, Orlowsky B, Mueller B, et al. 2014. Corrigendum: Global assessment of trends in wetting and drying over land. Nature Geoscience, 7: 848-852.

Groll M, Opp C, Kulmatov R, et al. 2015. Water quality, potential conflicts and solutions-an upstream-downstream analysis of the transnational Zarafshan River (Tajikistan, Uzbekistan). Environmental Earth Sciences, 73(2): 743-763.

Gu S, Yu X. 2017. Strategy of Xinjiang-Central Asia energy cooperation in Silk Road Economic Belt. China Oil \& Gas, 24(4): 29-33. (in Chinese)

Halvorson S J, Hamilton J P. 2007. Vulnerability and the erosion of seismic culture in mountainous Central Asia. Mountain Research and Development, 27(4): 322-330.

Hamidov A, Helming K, Balla D. 2016. Impact of agricultural land use in Central Asia: a review. Agronomy for Sustainable Development, 36(1): 1-23.

Held I M, Soden B J. 2006. Robust responses of the hydrological cycle to global warming. Journal of Climate, 19: 5686-5699.

Hojyaz J, Eshchanov R, Nurmetov J, et al. 2013. Canal lining to increase water use efficiency and remediate groundwater levels in Khorezm Uzbekistan, Central Asia. International Journal of Agriculture, 3(4): 742-750.

Howard K W, Howard K K. 2016. The new "Silk Road Economic Belt" as a threat to the sustainable management of Central Asia's transboundary water resources. Environmental Earth Sciences, 75(11): 976.

Hu Z, Zhang C, Hu Q, et al. 2014. Temperature changes in Central Asia from 1979 to 2011 based on multiple datasets. Journal of Climate, 27(3): 1143-1167.

Hu Z, Zhou Q, Chen X, et al. 2017. Variations and changes of annual precipitation in Central Asia over the last century. International Journal of Climatology, 37(Suppl. 1): 157-170.

Huang Q X, Zhao Y, He Q. 2013. Climatic characteristics in Central Asia based on CRU data. Arid Zone Research, 30(3): 396-403. (in Chinese)

Indoitu R, Orlovsky L, Orlovsky N. 2012. Dust storms in Central Asia: Spatial and temporal variations. Journal of Arid Environments, 85(10): 62-70.

Ioffe G, Nefedova T, Zaslavsky I. 2004. From spatial continuity to fragmentation: the case of Russian farming. Annals of the Association of American Geographers, 94(4): 913-943.

Jin L, Chen F, Morrill C. 2012. Causes of early Holocene desertification in arid central Asia. Climate Dynamics, 38(7-8): 1577-1591.

Karthe D, Chalov S, Borchardt D. 2015. Water resources and their management in Central Asia in the early twenty first century: status, challenges and future prospects. Environmental Earth Sciences, 73(2): 487-499.

Karthe D. 2018. Environmental changes in Central and East Asian drylands and their effects on major river-lake systems. Quaternary International, 475: 91-100.

Khamzayeva A. 2009. Water resources management in Central Asia: Security implications and prospects for regional cooperation. In: Khamzayeva A, Rahimov S, Islamov U, et al. Water Resources Management in Central Asia. Regional and International Issues at Stake. Barcelona: CIBOD Foundation, 9-32.

Kitamura Y, Yano T, Honna T. 2006. Causes of farmland salinization and remedial measures in the Aral Sea basin-Research on water management to prevent secondary salinization in rice-based cropping system in arid land. Agricultural Water Management, 85(1-2): 1-14.

Klein I, Gessner U, Kuenzer C. 2012. Regional land cover mapping and change detection in Central Asia using MODIS time-series. Applied Geography, 35(1-2): 219-234.

Klein I, Dietz A J, Gessner U, et al. 2014. Evaluation of seasonal water body extents in Central Asia over the past 27 years derived from medium-resolution remote sensing data. International Journal of Applied Earth Observation and 
Geoinformation, 26(2): 335-349.

Knorr W, Schnitzler K G, Govaerts Y. 2001. The role of bright desert regions in shaping North African climate. Geophysical Research Letters, 28(18): 3489-3492.

Kubo H, Tateno K, Watanabe A, et al. 2009. Human and environmental symbiosis in Central Asia: Through the water management of the Aral Sea Basin crisis. Transition Studies Review, 16(2): 467-478.

Kuemmerle T, Olofsson P, Chaskovskyy O, et al. 2011. Post-Soviet farmland abandonment, forest recovery, and carbon sequestration in western Ukraine. Global Change Biology, 17(3): 1335-1349.

Kushiev H, Noble A D, Abdullaev I, et al. 2005. Remediation of abandoned saline soils using Glycyrrhiza glabra: a study from the hungry steppes of Central Asia. International Journal of Agricultural Sustainability, 3(2): 102-113.

Kuzmina Z V, Treshkin S E. 2016. Climate Changes in the Aral Sea Region and Central Asia. Arid Ecosystems, 6(4): 227-240.

Lerman Z, Shagaida N. 2007. Land policies and agricultural land markets in Russia. Land Use Policy, 24(1): 14-23.

Levintanus A. 1992. Saving the Aral Sea. Journal of Environmental Management, 36(3): 193-199.

Li J L, Bao A M, Chen X, et al. 2017. The impact of Climate Change on Natural Resources and Environment in Central Asia. Beijing: China Meteorological Press, 105-107. (in Chinese)

Libert B, Lipponen A. 2012. Challenges and opportunities for transboundary water cooperation in Central Asia: findings from UNECE's regional assessment and project work. International Journal of Water Resources Development, 28(3): 565-576.

Lioubimtseva E, Cole R, Adams J M, et al. 2005. Impacts of climate and land-cover changes in arid lands of Central Asia. Journal of Arid Environments, 62(2): 285-308.

Lioubimtseva E, Cole R. 2006. Uncertainties of climate change in arid environments of Central Asia. Reviews in Fisheries Science, 14: 29-49.

Lioubimtseva E, Henebry G M. 2009. Climate and environmental change in arid Central Asia: impacts, vulnerability, and adaptations. Journal of Arid Environments, 73(11): 963-977.

Liu Y, Cheng Y P, Ge L Q. 2018. Analysis on exploitation status, potential and strategy of groundwater resources in the five countries of Central Asia. Journal of Groundwater Science and Engineering, 6(1): 49-57.

Micklin P. 2016. The future Aral Sea: hope and despair. Environmental Earth Sciences, 75(9): 844.

Ozturk T, Turp M T, Türkeş M, et al. 2017. Projected changes in temperature and precipitation climatology of Central Asia CORDEX Region 8 by using RegCM4.3.5. Atmospheric Research, 183: 296-307.

Pollner J, Kryspin-Watson J, Nieuwejaar S. 2008. Climate change adaptation in Europe and Central Asia: Disaster risk management. World Bank. [2008-06-22]. https://siteresources.worldbank.org/ECAEXT/Resources/258598-1243892418318/ DRM_and_Climate_Change.pdf.

Propastin P A, Kappas M, Muratova N R. 2008. A remote sensing based monitoring system for discrimination between climate and human-induced vegetation change in Central Asia. Management of Environmental Quality: An International Journal, 19(5): 579-596.

Puri S, Aureli A. 2010. Transboundary aquifers: a global program to assess, evaluate, and develop policy. Ground Water, 43(5): $661-668$.

Qadir M, Noble A D, Qureshi A S, et al. 2009. Salt-induced land and water degradation in the Aral Sea basin: a challenge to sustainable agriculture in Central Asia. Natural Resources Forum, 33(2): 134-149.

Rafikov V, Gulnora M. 2014. Forecasting changes of hydrological and hydrochemical conditions in the Aral Sea. Geodesy and Geodynamics, 5(3): 55-58.

Rakhimov M. 2010. Internal and external dynamics of regional cooperation in Central Asia. Journal of Eurasian Studies, 1(2): 95-101.

Rakhmatullaev S, Abdullaev I. 2014. Data management for integrated water resources management in Central Asia. Journal of Hydroinformatics, 16(6): 1425-1440.

Riedel F, Kossler A, Tarasov P, et al. 2011. A study on Holocene foraminifera from the Aral Sea and West Siberian lakes and its implication for migration pathways. Quaternary International, 229(1-2): 105-111.

Saiko T A, Zonn I S. 2000. Irrigation expansion and dynamics of desertification in the Circum-Aral region of Central Asia. Applied Geography, 20(4): 349-367.

Shen W, Miao Q, Wei T, et al. 2013. Analysis of temperature variation in recent 130 years in Central Asia. Journal of Arid Meteorology, 31(1): 32-36. (in Chinese)

Song S K, Bai J. 2016. Increasing winter precipitation over arid Central Asia under global warming. Atmosphere, 7: 139.

Sorg A, Bolch T, Stoffel M, et al. 2012. Climate change impacts on glaciers and runoff in Tien Shan (Central Asia). Nature Climate Change, 2: 725-731.

Stocker T F, Qin D H, Plattner G K. 2013. Working group I contribution to the IPCC fifth assessment report climate change 
2013: the physical science basis. Final draft underlying scientific-technical assessment IPCC. Stockholm, Switzerland.

Stunzhas P A. 2016. Calculation of electric conductivity of water of the Aral Sea and correction of the sound salinity of 2002-2009. Oceanology, 56(6): 782-788.

Suleimenov M. 2014. Trends in the agriculture of Central Asia and implications for rangelands and croplands. In: Mueller L, Saparov A, Lischeid G. Novel Measurement and Assessment Tools for Monitoring and Management of Land and Water Resources in Agricultural Landscapes of Central Asia. Environmental Science and Engineering. Heidelberg: Springer, Cham, 91-105.

Thevs N, Zerbe S, Kyosev Y, et al. 2012. Apocynum venetum L. and Apocynum pictum Schrenk (Apocynaceae) as multi-functional and multi-service plant species in Central Asia: A review on biology, ecology, and utilization. Journal of Applied Botany and Food Quality, 85(2): 159-167.

Unger-Sayesteh K, Vorogushyn S, Farinotti D, et al. 2013. What do we know about past changes in the water cycle of Central Asian headwaters? A review. Global and Planetary Change, 110: 4-25.

Varis O. 2014. Resources: curb vast water use in central Asia. Nature, 514: 27-29.

Wang J S, Chen F H, Zhang Q, et al. 2008. Temperature variations in arid and semi-arid areas in middle part of Asia during the last 100 years. Plateau Meteorology, 27(5): 1035-1045. (in Chinese)

Wang J S, Wei F, Feng J Y. 2011. Impact of sea surface temperature anomaly on two global warming periods in the $20^{\text {th }}$ century over the arid Central Asia. In: 2011 IEEE International Geoscience and Remote Sensing Symposium. $24-29$ July 2011. Vancouver, BC, Canada, 3249-3252.

Wang J S, Wei F. 2012. Impact of 500hpa height field anomaly on precipitation and temperature change over arid Central Asia over the past 100 years. In: 2012 IEEE International Geoscience and Remote Sensing Symposium. 22-27 July 2011. Munich, Germany, 868-871.

White K D. 2013. Nature-society linkages in the Aral Sea region. Journal of Eurasian Studies, 4(1): 18-33.

Wu F, Fang X, Herrmann M, et al. 2011. Extended drought in the interior of Central Asia since the Pliocene reconstructed from sporopollen records. Global and Planetary Change, 76(1-2): 16-21.

Xu H, Li Y, Xu G Q, et al. 2007. Ecophysiological response and morphological adjustment of two Central Asian desert shrubs towards variation in summer precipitation. Plant, Cell \& Environment, 30(4): 399-409.

Xu T, Shao H, Zhang C. 2015. Temporal pattern analysis of air temperature change in Central Asia during 1980-2011. Arid Land Geography, 38(1): 25-35. (in Chinese)

Yang D G, Du H R. 2013. An Outline of Economic Geography of Central Asia. Beijing: China Meteorological Press, 13-18. (in Chinese)

Yao J, Chen Y. 2015. Trend analysis of temperature and precipitation in the Syr Darya Basin in Central Asia. Theoretical and Applied Climatology, 120(3-4): 521-531.

Yin G, Hu Z, Chen X, et al. 2016. Vegetation dynamics and its response to climate change in Central Asia. Journal of Arid Land, 8(3): 375-388.

Yu Y, Disse M, Yu R D, et al. 2015. Large-scale hydrological modeling and decision-making for agricultural water consumption and allocation in the main stem Tarim River, China. Water, 7(6): 2821-2839.

Yu Y, Yu R D, Chen X, et al. 2017. Agricultural water allocation strategies along the oasis of Tarim River in Northwest China. Agricultural Water Management, 187: 24-36.

Zerbe S, Thevs N. 2011. Restoring Central Asian floodplain ecosystems as natural capital and cultural heritage in a continental desert environment. In: Hong S K, Kim E, Wu J, et al. Landscape Ecology in Asian Cultures. Ecological Research Monographs. Tokyo: Springer, 277-297.

Zhang K, Kimball J S, Nemani R R, et al. 2010. A continuous satellite-derived global record of land surface evapotranspiration from 1983 to 2006. Water Resources Research, 46(9): 109-118.

Zhou H, Aizen E, Aizen V. 2013. Deriving long term snow cover extent dataset from AVHRR and MODIS data: Central Asia case study. Remote Sensing of Environment, 136: 146-162. 